\title{
Identity on Private Universities' Billboards in Yogyakarta
}

\author{
Irene Santika Vidiadari \\ Universitas Atma Jaya Yogyakarta, Jl Babarsari 44 Yogyakarta 55281 \\ E-mail: irene.vidiadairi@uajy.ac.id
}

\begin{abstract}
This research discusses identity as the visual means of private universities to attract prospective students. The data was collected by documenting billboard advertisements located on the arterial road of the City of Yogyakarta that contain visual and linguistic aspects. The gathered data are four billboards of private universities. Applying the multimodal analysis of Gunther Kress and Theo van Leeuwen, this study examines the billboard text to understand the visual and linguistic aspects as well as the relation between them to construct the commodification of education discourses. This research has found that identity becomes a highlighted aspect of the billboards of private universities. The visualization of the identity appears as on physical characters and attributes wore by the students or the models. There are three identities generally appearing, (1) university identity, through the alma mater jacket; (2) tribal/ethnic identity, through the physical appearance of the models; and (3) religious identity, through the fashion style. The sloganse.g. 'Welcome, the Smart and Humanist Generation' and Excellent, Inclusive, Humanist, [with] Integrity'-written on the billboards, from the perspective of linguistic, represent the ideology of the educational institutions. The slogan is not only an enhancer but also a means to build and modify the meaning of the advertisement. Furthermore, it also becomes the representation of what kind of higher-education services are offered by the institution. The modification of the message through identity issues shows exclusivity, while the cultural identity indicates the inclusivity on the campus.
\end{abstract}

Keywords: Billboard, Higher Education, Identity, Multimodal analysis.

\section{INTRODUCTION}

Higher education is stage one goes through after finishing primary and secondary education. In Indonesia, there are two kinds of higher-level educational institutions (college/university), namely the state and private universities. The state universities are the most favorite institutions among high-school graduates. In 2017, the Joint-Selection Committee of State-Owned University Entrance Exam (Panitia Seleksi Bersama Masuk Perguruan Tinggi) recorded 39,305 highschool graduates were applying for the entrance exam. The following year, the number of applicants increased by 3,000 (Kumparan, 2018). In Yogyakarta, there are four state-owned universities, namely UGM, UNY, UIN Sunan Kalijaga, and
UPN Veteran. Due to the popularity of state-owned universities, as well as the reputation of those four universities, Yogyakarta's state-owned universities need not bother with promoting their institutions to attract prospective students. For private universities, however, the situation is quite different.

In the Province of the Special Region of Yogyakarta, there are 106 private higher education institutions, 19 of which are universities (Ristekdikti, 2017). There are 607 study programs, 412 of which have been accredited by A and B, while the rest are $\mathrm{C}$ because they are new study programs in their respective universities (Jawapos, 2018). The growing number of new study programs implies that the need to obtain new students is also increasing. 
As a consequence, the competition to gather new students has become quite tight. The private universities have to come up with fresh ideas to promote their institutions.

Moreover, as argued by Lupiyoadi (Lupiyoadi, 2011), there is another factor that makes the competition of the higher-level education industry more aggressive. It is the issuing of the Government's Regulation (Peraturan Pemerintah) No. 61 the year 1999 on Higher-Education Institution Autonomy (Otonomi Perguruan Tinggi), that has given opportunities for each HigherLevel Education Institution (Perguruan Tinggi or PT) to come up with a more efficient way to govern themselves which will eventually affect the advancement of science. Briefly speaking, colleges/ universities given space to grow and develop along with the state colleges/ universities.

Besides visiting schools, promoting the institution on the official website, spreading brochures, the private universities employ another strategy to attract prospective students, namely putting advertisements, either indoor or outdoor. Sopandi (2011) asserts that an advert, either printed or electronic, is the most dominant variable in the effort to attract prospective students. An advertisement is every presentation that is paid for [delivering] non-private ideas, goods, or services, which are introduced by a sponsor. It makes use of various media such as magazines, newspapers, audio-visual media, billboards, directmail (subscription), at so on. Rini (2018, p. 97) argues that advertising is a promotion to introduce a product as well as strengthen the product image in the minds of consumers.

However, although the world becomes more and more digital, people are still promoting their products on billboards. The annual report of Outdoor
Advertising Association of America (OAAA, 2017) unveils that the income of outdoor advertisement, namely billboards, is still the highest $(66,1 \%)$ among any other outdoor media such as transit $(17,4 \%)$, place-based media $(11,3 \%)$, and street furniture $(5,2 \%)$. Therefore it is only natural that private universities make use of billboards to attract the attention of high-school graduates.

It is an irony that the audience, despite their familiarity with the most popular means of promotion, namely advertisements, sometimes forget that it is a form of discourse, as a language system used in daily life (Ikaria-Maina, 2014, p. 1562). How an advertisement in the media presented can never be disconnected from the discourse produced by the advertisers. Cook (2001, p. 4) argues that advertisement, even though aimed at selling or promoting goods or services, contains text impregnated with the discourses of the producers.

Yogyakarta, as the City of Students, has now become an open battlefield to fight over prospective students. The billboards put on several spots on major arterial roads (jalan protocol), such as Jalan Solo, Gejalan, and Kusumanegara. For private universities, billboards function as a medium to convey ideas about the "product" offers as well as a means to represent themselves. Each university billboard has unique characters that differentiate it from the others. One of the most distinctive representations on the university billboards is related to identity, which emphasizes the visual image or text.

Research on the identity of educational billboards in Indonesia is still not popular. Therefore it is quite challenging to seek previous studies on this subject. However, there are several interesting studies on identities that have been performed by Indonesian scholars. Sulastri and Ronidin (2014) study 
billboards of the political campaign in West Sumatera and have published their interesting findings on "The Billboards Language Phenomenon as the Figures' Self-Identity which Reflects Cultural Character: Semiotic Study" (Fenomena Bahasa Baliho sebagai Identitas Diri Tokoh Cerminan Karakter Budaya: Kajian Semiotika). They found that the language on the billboards was used to represent identity and was formed based on certain ideologies. It answers the question of why billboards often use local language as well as employing rhymes; it is going to be easier for the audience to remember the message, as well as the ideology, that the advertiser is trying to convey.

Haryono and Putra (2017) in "Indonesian Cultural Identity: Roland Barthes' Semiotics Analysis on Aqua's Find Your Indonesia Advertisement" argue that on an advertisement, the Indonesian culture constructed through visual and audio signs that show Indonesian identity through traditional clothing (for example batik), norms, character, language, and habit. The advertisements also feature people kissing the hands of the elderly and people greeting each other to construct the identity of Indonesian society: friendly and respectful.

An advertisement is a type of promotion which aims at persuading the audience to use the goods or services. It contains messages offering a product to the public through certain media (Kasali, 2002). Kottler and Armstrong (Kottler \& Armstrong, 2009, p. 236) argue that an advertisement is a form of promotion for individuals, organizations, or corporations to deliver their vision and mission. The advertisement text contains the product name as well as ideas or services which could give benefit to the users or consumers, employed to inform, remind, and to persuade the consumers to consume the advertised products. Susanto (2014, p. 3) argues that the strength of an advertisement lies in the sophistication as well as the [advertiser] perspective in formulating and organizing messages so that it can attract [targets] and be able to construct similar meanings between the sender of the advertising message and the audience.

Ikaria-Maina (2014, p. 1562) suggested that advertising can be divided into three main categories: (1) consumer advertisements directed at promoting a product or service to the general public; (2) commercial advertisements aimed at the audiences through certain media; and (3) public service advertisements delivered to the public by stakeholders or social groups to build awareness of an issue.

As a type of outdoor advertisement, a billboard is put on strategic locations, containing short messages so that the audience only needs a short period to read and understand the contents (Banda \& Oketch, 2011, p. 23). In other words, a billboard is a strategic 2-dimensional promotional media to remind and strengthen the audience's memory about the ideas about the promoted product.

Banda and Oketch (2011) on "Localizing HIV/AIDS Discourse in a Rural Kenyan Community" assert that based on one of their findings that there are images which are incompatible with the reality of daily life of the rural community, the compatibility between the words and visual [image] on the billboards determines the success of the campaign. Messages on an advertisement are text, although, in reality, they contain both visual and linguistic elements. Norris (Sinar, 2012, p. 312) argues that a text that is a unit of language that possesses meaning in a social context exists because communication interaction occurs. The whole communication interaction is what we call multimodal. An advertisement, as a multimodal text consisting of image, writing, or sound, gives a palpable 
illustration that the verbal and non-verbal elements of a text can not be disconnected (Ademilokun \& Olateju, 2016, p. 2). A text which is studied using the systemic functional approach, as applied to this current research, will emphasize the meaning constructed on the whole element of the text.

An advertisement as a multimodal text implies that it contains more than one discourse text mode (Putri, 2016, p. 27). Meanwhile, modality, according to van Leeuwen (2005, p. 160), is a social semiotical approach to the questions of truth related to the issues of representation in the media. In other words, modality is not used for obtaining the absolute reality of truth but for comprehending the concepts represented in the media. In multimodal discourse analysis, the text is considered a multimodal semiotic entity, no matter in what shape it appears is the result of semiotic designing work as well as the production and composition process. In other words, the text is a result of the mix between the different styles of composition and rests on semiotic work that produces an effect on such text producer (Gunther Kress, 2013, p. 36).

Cultural identity is a concept which explains the self-concept of an individual or a group (Samovar et al., 2015, p. 76). Mostly constructed through the association to a societal group, while the rest is upon the individual's/ group's initiative, expressed through norms, habits, and rules expressed through symbols, either verbal or visual. It is the reason why we can identify one particular thing to another. Such an example is batik (the traditional Javanese fabric); we could associate parang rusak motive with Yogyakarta because it is one of the symbols indicating the identity of the city.

Collier (2015, p. 53) discusses cultural concept as the system of symbols, meanings, and norms that are distributed continuously from one generation to the next. In practice, the culture, as a system, consists of three components: symbolmeaning, norms, and history. Symbols play an important role in identity that one can associate with an identity. In the advertisement, for instance, the identity symbol could be a means of persuasion because regarded as close to the audience (Rohmiati, 2010, p. 39). The emphasis on identity symbols in the advertisement is indicated by the cultural attribute, including language, geographic [image], and cultural artifacts such as clothing, traditional house, music, or dance. Furthermore, identity issues are used in the promotion of private universities. The emphasis on identities on the university billboards can also show us the discourse of education in the city of Yogyakarta.

\section{METHODS}

This study uses the multimodal analysis of Gunther Kress and Leuween (2006, p. 36) to indicate that all of the elements of verbal and non-verbal communication have their roles in shaping meaning (O'Halloran, 2004, p. $5)$. Multimodal is one of the analyses involvingtheinteractionand theintegration of text consisting of one or more semiotic sources or means of communication to fulfill the communicative function of the text. This multimodal analysis studies the visual and linguistic aspects of the private university billboards in Yogyakarta and perceives the inter-mode relations. The object of this research is four private university billboards in Yogyakarta, namely Universitas Sarjanawiyata Tamansiswa, Universitas Sanata Dharma, Universitas Teknologi Yogyakarta, and Universitas Atma Jaya Yogyakarta, all of them positioned on a major arterial road. The data gathering was conducted in June 2018 by taking billboard pictures on arterial roads. Each university is only represented by one billboard because the photo was taken for a limited period. 
The four billboards selected base on the criteria that support the discussion of identity that appears in billboard advertisements through visual and linguistics. The data analysis uses the analytical framework of Kress and Leuween (2006, p. 177) on composition. They stated that it is the relation between the meaning representation and interactivity of an image and other modes through an interconnected system. It is perceived from the information placement, the dominant mode, and the information framing on billboards. The framing (Gunther; Kress \& Leeuwen, 2006, pp. 203-204), concerns the intermodal connection of every media appearance (in which context are billboards). They also argue about corresponding (connection) and noncorresponding (disconnection) elements to discuss the degree of correlation between the visual and verbal elements as well as the information framing of a billboard advertisement. After examining the visual and linguistic data, the next stage of analysis is finding out the aspects of information value, salience, and framing (Kress and Leeuwen, 2006, p. 177-210). The information value sees the placement of visual and linguistic elements that give information to the reader.

How information is placed can be seen from the position of the billboards posted by the advertiser: from left to right, from top to bottom, or from the middle to the side (Kress and Leeuwen, 2006, p. 177). The part that stands out helps us understand which advertisement element attract the attention of the audience/ reader (Kress and Leuween, 2006, p. 177). The various degrees in which the foreground or background selection appears, size, color contrast, color sharpness, at so on indicate the salience. The last aspect is the framing. Framing, in Kress and Leuween (2006, p. 203204), is also about the intermodal relation of each media presentation (in which case is the billboards). Furthermore, Kress and Leuween (2006, p. 210) discuss connected elements (connection) and disconnected elements (disconnection), both of which see the degree of correlation between visual and verbal elements as well as the information framing of a billboard advertisement. If each mode is connected, the frame will work to unify the information value and salience to become compact information.

\section{FINDINGS AND DISCUSSION}

On Multimodal Discourse Analysis, the text is a multimodal semiotic-entity. Text, regardless of its shape, is a result of semiotic-planning work as well as the production and composition process. The text becomes the result of the combination of different style-composition, resting on the semiotic works that give a particular effect on similar text producers (Gunther Kress, 2013, p. 36).

Therefore, the Multimodal Discourse Analysis also emphasizes that all communication elements, either verbal or nonverbal, play their role in shaping meanings (O'Halloran, 2004, p. 5). It involves the interaction and integration of text consisting of two or more semiotic sources (means of communication) to achieve the communication function.

On Multimodal Discourse Analysis, the text is a multimodal semiotic-entity. Text is a result of semiotic-planning work as well as the production and composition process regardless of its shape. It becomes the result of the combination of different style-composition, resting on the semiotic work that gives a particular effect on similar text producers (Gunther Kress, 2013, p. 36).

Therefore, the Multimodal Discourse Analysis also emphasizes that all communication elements, either verbal or nonverbal, play their role in shaping meanings (O'Halloran, 2004, p. 5). It 
involves the interaction and integration of text consisting of two or more semiotic sources (means of communication) to achieve the communication function.

The advancement of multimodal analysis contributes to the development of a theoretical framework to articulate the meaning of a multi-semiotic text, for the reason that the research on the latter field is not as advanced as theoretical linguistics. Accordingly, the research on the multimodal text will integrate the analysis on visual and linguistic components (Cheong, 2004, p. 163), and the data findings divided into three aspects: the visual, linguistics, and the relation between visual and linguistics. An advertisement as a multimodal text implies that it contains more than one discourse text mode (Putri, 2016, p.
27). Meanwhile, modality, according to van Leeuwen (2005, p. 160), is a social semiotical approach to the questions of truth related to the issues of representation in the media. In other words, modality is not used for obtaining the absolute reality of truth but for comprehending the concepts represented in the media. In multimodal discourse analysis, the text is considered as a multimodal semiotic entity. No matter in what shape, the text appeared is the result of semiotic designing work as well as the production and composition process. In other words, it is a result of the mix between the different styles of composition and rests on semiotic work that produces an effect on such text producer (Gunther Kress, 2013, p. 36).

TABLE 1. The Visual Aspect Identification of the Billboards

\begin{tabular}{|c|c|c|c|c|}
\hline Aspect & $\begin{array}{c}\text { Universitas Atma } \\
\text { Jaya Yogyakarta }\end{array}$ & $\begin{array}{c}\text { Universitas } \\
\text { Sanata Dharma }\end{array}$ & $\begin{array}{c}\text { Universitas } \\
\text { Teknologi } \\
\text { Yogyakarta }\end{array}$ & $\begin{array}{c}\text { Universitas } \\
\text { Sarjanawiyata } \\
\text { Tamansiswa }\end{array}$ \\
\hline Lead & $\begin{array}{l}\text { Billboard color: } \\
\text { yellow } \\
\text { The billboard } \\
\text { consists of two } \\
\text { (2) sections: } \\
\text { the information } \\
\text { section and the } \\
\text { visualization of } \\
\text { a group of youth } \\
\text { interacting with a } \\
\text { Javanese puppet } \\
\text { master (dalang). }\end{array}$ & $\begin{array}{l}\text { Billboard color: } \\
\text { red and gold } \\
\text { The billboard } \\
\text { consist of two } \\
\text { (2) sections: } \\
\text { the information } \\
\text { section and the } \\
\text { visualization } \\
\text { of [a] student } \\
\text { standing facing } \\
\text { forward with the } \\
\text { campus as the } \\
\text { background. }\end{array}$ & $\begin{array}{l}\text { Billboard color: } \\
\text { red and blue } \\
\text { The billboard } \\
\text { consists of two } \\
\text { (2) sections: } \\
\text { the information } \\
\text { section and the } \\
\text { visualization of a } \\
\text { group of students } \\
\text { hand in hand with } \\
\text { the campus as the } \\
\text { background }\end{array}$ & $\begin{array}{l}\text { Billboard color: } \\
\text { light green, dark } \\
\text { green, and white } \\
\text { Students wearing } \\
\text { alma mater suits. } \\
\text { One of them } \\
\text { wears the hijab. } \\
\text { There are also } \\
\text { three images of } \\
\text { youth wearing } \\
\text { traditional } \\
\text { clothing on the } \\
\text { bottom side. }\end{array}$ \\
\hline Display Emblem & $\begin{array}{l}\text { Implicit } \\
\text { University logo } \\
\text { on the top left } \\
\text { and on the left } \\
\text { side, on the } \\
\text { yellow bag (tote } \\
\text { bag) and the } \\
\text { dark-blue pouch }\end{array}$ & $\begin{array}{l}\text { Explicit } \\
\text { University } \\
\text { logo and the } \\
\text { accreditation } \\
\text { logo }\end{array}$ & $\begin{array}{l}\text { Explicit } \\
\text { University logo }\end{array}$ & $\begin{array}{l}\text { Explicit } \\
\text { University } \\
\text { logo and the } \\
\text { accreditation } \\
\text { logo }\end{array}$ \\
\hline
\end{tabular}

Source: The primary data 


\section{The Visual Aspects of Billboard Advertisement}

The visual aspects are the image presentation and color used on the university billboards. The visual aspect examined is lead, display, and emblem. In all of the billboards, the identity appears on the lead aspect, a part of the visual component which is more emphasized through the choice of color, size, and position (Gunther; Kress \& Leeuwen, 2006).

The TABLE 1 illustrates that the universities present their identities through color, logo, information about accreditation status, and visualization represented by the image of the students and the university campus. The billboard of Universitas Sarjanawiyata Tamansiswa shows the identity through the advertisement model image who are wearing the alma mater suits; the other picture shows a pair of students wearing traditional Balinese clothes, and also there is a picture of female students performing a traditional dance. On the billboard of Universitas Teknologi Yogyakarta, the identity is shown through a group of people hand in hand while lifting one of their own feet. The group of people featured in the picture wears different items of clothing. Several of the females wear the hijab, while several males put on a shirt. The billboards of Universitas Sanata Dharma and Universitas Atma Jaya feature the models having different physical appearances that show that they are from diverse ethnic groups. Interestingly, on the billboards of those two Catholic universities, there are hijabwearing models. In general, there are two emphasized identities, namely the religious identity as hijab-wearing female and university identity shown through the picture of the university campus in the background.

As the symbol of the religion of the majority in Indonesia, Islam, the hijab appears on the billboard of all of the four universities, the hijab-wearing models on the billboards of Universitas Teknologi Yogyakarta and Universitas Sarjanawiyata Tamansiswa-both of which are universities without any religious affiliations-illustrate the reality of their students' diverse identity. For Universitas Atma Jaya Yogyakarta and Universitas Sanata Dharma, both Catholic universities, the hijab-wearing model is an appeal as a non-exclusive educational institution that does not only open for students from certain religions but also that of various and different. It gives both universities an air of inclusiveness, an added value that hopefully attract prospective students. It is related to the issues of religious differences that bring out conflicts in society. One of the cases is the taking down of the billboard of Universitas Kristen Duta Wacana (UKDW) by Front Umat Islam (the Islamic Follower Front or FUI) because it featured the Muslim female model (BBC, 2016). In contrast to UKDW, Sanata Dharma University (USD) was also asked to dismantle a billboard featuring a woman in a veil but was rejected by the USD Chancellor because this image represented USD, which has $17 \%$ non-Christian students (Pitaloka, 2016).

Another identity that appears on the billboard is "acknowledgment" which is the university's accreditation status. In Indonesia, it is important because they believe that accreditation status is related to alumni careers. For example, it is a common practice that companies only seek the candidate of workers from certain reputable high-accredited universities. When an individual wants to take the test to become a civil servant, he/she must attach both the university and accreditation information letter for the study program. 


\section{The Linguistic Aspects of the Billboards}

The linguistic aspect of multimodal analysis does not focus on lexicon or semantics as applied to other linguistic researches. Cheong (2004, pp. 173-174) elaborates that the linguistic aspect of multimodal text research discusses the shaping of meaning through sentences featured in advertisements and the completeness of information for the audience to access the advertisement products. The linguistic aspects discussed on billboards are:

- Announcement: On the printedadvertisement, the most prominent linguistic element is "announcement." The emphasis appears through the font color, type, and size(Cheong, 2004, p. 173). There are two kinds of announcements: primary and secondary announcement. The first is only appearing in an advertisement that emphasizes more of interpersonal announcement character compared to the other type on the same ads and becoming the most memorized sentence. The secondary announcement, on the other hand, is the less stand-out announcement.

- Enhancer: The enhancer solely consists of the linguistic components, usually in the form of a paragraph whose function is to build or modify the meaning originated from the interaction between the "lead" and "announcement." It is employed to persuade and influence the audience to purchase the advertised products (Cheong, 2004, p. 173).

- Emblem: Linguistically, the emblem shows up as the name/brand of the advertised product or service. It indicates the product identity and can be installed anywhere in the ads (Cheong, 2004, p. 173).

- Tag: excluded information from the whole message will be dispatched through a "tag". It serves as a recommendation about the advertisedproducts. The tag is commonly a short sentence in small fonts that does stand out in the ads (Cheong, 2004, p. 174).

- Call and visit information: the contact information, e.g. telephone number, internet website, location, or how to get the advertised-product. Usually, this component does not attract attention, and it is written in a relatively smaller font compared to other information in the ads (Cheong, 2004, p. 174).

Based on TABLE 2, all four billboards, the university identity appears on the aspect of enhancer, namely words function to construct and modify the meaning which comes from the interaction between lead (in visual aspect) and announcement. The slogan written on the billboards, from the perspective of linguistic, represents the ideology of the educational institutions. This research has found that among the four universities, only two of which use a slogan to promote their education service, namely Universitas Sanata Dharma and Universitas Atma Jaya Yogyakarta. The slogans on Universitas Sanata Dharma billboards are: (1) "Selamat Datang Generasi Cerdas Humanis" (Welcome Intellect Humanist Generation). The phrase "Selamat Datang" (welcome) use as an interpersonal approach by the advertiser to the audience; and (2) "Cerdas, Humanis, Cinta Kebenaran" (Intellect, Humanist, Truth-Loving). Meanwhile, the billboard of Universitas Atma Jaya features "Unggul, Inklusif, Humanis, Berintegritas" (Excellent, Inclusive, Humanist, Having-Integrity) which is also the slogan of the university.

The slogan is not only an enhancer but also a means to build and modify the meaning of the advertisement. Furthermore, it also becomes the representation of what kind of highereducation services are offered by the institution. On the billboards of Sarjanawiyata Tamansiswa, the enhancer is the following sentence: "Pilihan 
Irene Santika Vidiadari. Identity on Private Universities' Billboards...

TABLE 2. The Linguistic Aspect Identification of the Billboards

\begin{tabular}{|c|c|c|c|c|}
\hline Linguistic Aspect & $\begin{array}{l}\text { Universitas Atma } \\
\text { Jaya Yogyakarta }\end{array}$ & $\begin{array}{c}\text { Universitas } \\
\text { Sanata Dharma }\end{array}$ & $\begin{array}{l}\text { Universitas } \\
\text { Teknologi } \\
\text { Yogyakarta }\end{array}$ & $\begin{array}{c}\text { Universitas } \\
\text { Sarjanawiyata } \\
\text { Tamansiswa }\end{array}$ \\
\hline $\begin{array}{l}\text { Primary } \\
\text { Announcement }\end{array}$ & $\begin{array}{l}\text { The name of the } \\
\text { institution. } \\
\text { On the left side: } \\
\text { "Unggul, Inklusif, } \\
\text { Humanis, dan } \\
\text { Berintegritas" } \\
\text { "Excellent, Inclu- } \\
\text { sive, Humanist, } \\
\text { [with] Integrity" } \\
\text { Information about } \\
\text { admission. }\end{array}$ & $\begin{array}{l}\text { The university } \\
\text { name }\end{array}$ & $\begin{array}{l}\text { Information about } \\
\text { student admission } \\
\text { through three types } \\
\text { of intakes: PMDK, } \\
\text { Scholarship, } \\
\text { Regular }\end{array}$ & $\begin{array}{l}\text { The announcement } \\
\text { of the student } \\
\text { admission in the } \\
\text { academic year of } \\
2018 / 2019\end{array}$ \\
\hline $\begin{array}{l}\text { Secondary } \\
\text { Announcement }\end{array}$ & $\begin{array}{l}\text { The universities' } \\
\text { social media } \\
\text { account }\end{array}$ & $\begin{array}{l}\text { Information about } \\
\text { student admission }\end{array}$ & N/A & $\begin{array}{l}\text { The selection } \\
\text { schedule, available } \\
\text { departments, types } \\
\text { of class (regular } \\
\text { and worker), } \\
\text { the admission } \\
\text { information }\end{array}$ \\
\hline Enhancer & $\begin{array}{l}\text { Writing: } \\
\text { Excellent, } \\
\text { Inclusive, } \\
\text { Humanist, } \\
\text { [with] Integrity, } \\
\text { emphasized by } \\
\text { an image on the } \\
\text { right side of the } \\
\text { billboard }\end{array}$ & $\begin{array}{l}\text { "Welcome, } \\
\text { the Smart and } \\
\text { Humanist } \\
\text { Generation" }\end{array}$ & N/A & $\begin{array}{l}\text { Tagline: "The } \\
\text { choices of the } \\
\text { prospective } \\
\text { study program, } \\
\text { [with] quality } \\
\text { and accredited by } \\
\text { BAN-PT" }\end{array}$ \\
\hline Emblem & $\begin{array}{l}\text { Writing: } \\
\text { "Universitas Atma } \\
\text { Jaya Yogyakarta'on } \\
\text { the top left }\end{array}$ & $\begin{array}{l}\text { The university } \\
\text { name, the } \\
\text { announcement of } \\
\text { intake via PMB } \\
\text { (student intake), } \\
\text { PMB schedule }\end{array}$ & $\begin{array}{l}\text { The university } \\
\text { name }\end{array}$ & $\begin{array}{l}\text { The university } \\
\text { name }\end{array}$ \\
\hline Tag & N/A & N/A & $\begin{array}{l}\text { Writing 'The } \\
\text { Better Choice' }\end{array}$ & $\mathrm{N} / \mathrm{A}$ \\
\hline $\begin{array}{l}\text { Call and Visit } \\
\text { Information }\end{array}$ & $\begin{array}{l}\text { PMB information, } \\
\text { via telephone, } \\
\text { website, and social } \\
\text { media. The font } \\
\text { size is small yet } \\
\text { quite highlighted }\end{array}$ & $\begin{array}{l}\text { University website, } \\
\text { telephone number, } \\
\text { and campus } \\
\text { address }\end{array}$ & $\begin{array}{l}\text { Website and } \\
\text { contact number }\end{array}$ & $\begin{array}{l}\text { Website, university } \\
\text { address, official } \\
\text { social media } \\
\text { account }\end{array}$ \\
\hline
\end{tabular}

Source: The primary data

Program Studi Prospektif, Berkualitas dan Terakreditasi BAN-PT." (The choices of the prospective study program, [with] quality and accredited by BAN-PT.) The line shows the effort of the university to show that their chosen study-program has gotten acknowledgment from the government (BAN-PT). On the billboards of Universitas Teknologi Yogyakarta, the use of the linguistic aspect lies in 
the line "The Better Choice" which is not followed by any explanations. The intermodal relation of each billboard can be seen from TABLE 3 .

Based on TABLE 3, among four private university billboards, three of them use visual as the dominant mode while one billboard features linguistic. Visual mode is pictures that predominate the use of space on the billboards, either picture of campus facility, namely the university building, or other such as the diversity of the students.

The diversity of students are featured on all billboards. Universitas Atma Jaya Yogyakarta and Universitas Sanata Dharma show diversity through the physical appearance of the students, e.g. the eye shape and skin color representing tribe and race as well as fashion attributes such as hijab that represent religious diversity. Unlike these two universities, Universitas Teknologi Yogyakarta vaguely shows the identity of the students. There is no emphasized identity except for the difference in what the students wear - the female students wear hijab, while the males wear suits and shirts. Meanwhile, Universitas Sarjanawiyata Tamansiswa features the diversity in traditional dance and costume as the visualization of non-academic activities of the students.

It mainly focuses on the primary announcement, namely the announcement on the admissions - through PMDK, scholarship, and regular-placed on the left side of the billboard. However, it is possible that a secondary announcement, as an additional feature, is not included on a billboard. Referring to Cheong (2004, p. 173), the enhancer is a linguistic element as paragraphs, which modifies the meaning originated from the interaction between lead and announcement. The function of an enhancer is to allure and influence the audience to buy products through an emotional approach. White (1999, in Cheong, 2004, p. 173) argues that enhancer ideally explains the reason why the product is worth to consume or to be chosen compared to other products. The tag and enhancer are elements that convey an emotional approach to the audience through the recommendation given by the advertiser in a paragraph or a

TABLE 3. Intermode Relation

\begin{tabular}{|c|c|c|c|c|}
\hline \multirow{2}{*}{ No. } & \multirow{2}{*}{ University Billboard } & \multicolumn{2}{|c|}{ Dominant Mode } & \multirow{2}{*}{ Elements that Appear } \\
\hline & & Visual & Linguistik & \\
\hline 1 & $\begin{array}{l}\text { Universitas Atma Jaya } \\
\text { Yogyakarta }\end{array}$ & $\mathrm{v}$ & & - Tag \\
\hline 2 & $\begin{array}{l}\text { Universitas Sanata } \\
\text { Dharma }\end{array}$ & $\mathrm{v}$ & & - Tag \\
\hline 3 & $\begin{array}{l}\text { Universitas Teknologi } \\
\text { Yogyakarta }\end{array}$ & $\mathrm{v}$ & & $\begin{array}{l}\text { - Secondary announcement } \\
\text { - Enhancer }\end{array}$ \\
\hline 4 & $\begin{array}{l}\text { Universitas } \\
\text { Sarjanawiyata } \\
\text { Tamansiswa }\end{array}$ & & $\mathrm{v}$ & - Tag \\
\hline
\end{tabular}


short sentence whose font is not dominant. This research finds that the advertisers (in which context is the universities) are depending more on visual and linguistic elements such as lead, display, and an announcement when promoting their institution instead of using an additional element as a recommendation through tag and enhancer.

\section{Information Value, Salience, and Framing}

Information value is an aspect through which we can see the placement of each element of billboard presentation, either picture or written text, that gives information to the audience/reader. The information placement is perceived by in which position (information) is put by the billboard advertiser: from left to right, up to bottom, or middle to the sides (Kress and Leeuwen, 2006, p. 177). The information placement zone of a billboard is important for a multimodal analysis (Kress and Leuween, 2006, p. 184-185). The left-right position represents the 'given and new' meaning that the information is updated. The other zone, up to the bottom, represents an ideal-real value shown through the up-bottom image composition (Kress and Leeuween, 2006, p. 186). Kress and Leuween argue that in media the upper zone is for the ideals, while the lower is for real things. In other words, the abstract information is put on the upper, while the real information is on the bottom. The last zone discussed by Kress and Leuween (2006, p. 194) is the middle-sides zone. This zone could combine the composition of information placed on the other two zones. All types of information, given or new, ideal or real, could be put in the middle-sides zone. The information value on the university billboards we study is more likely to be conveyed through the linguistic elements, as clearly seen on the billboard of Universitas Sarjanawiyata
Tamansiswa.

On the billboard of Universitas Sanata Dharma and Universitas Teknologi Yogyakarta, on the left side, there is an image of students in front of the campus. By referring to Kress and Leuween (2006), the visual of the students on the left-side is the representation of given information, namely about the campus environment and the diverse background of the students. The right-side contains information about admissions, namely 'the new information'.

The billboard of Universitas Atma Jaya also uses the left-right composition to convey information. The left side of the billboard contains information about the name of the institution, the values (through a tagline: Inclusive, Excellent, Humanist, and [with] Integrity), and the information about admissions (contact numbers). It provided the institution name, grade, and admission information. Pictures of several young people surrounding the elderly holding a puppet (wayang) convey this new information. This research also finds the information placed on the two-layered zone (leftright and up-bottom) on the university billboards. One of the examples is the billboard of Universitas Sarjanawiyata Tamansiswa. The producer puts the admission (PMB) information on the left side of the billboard, while the image of students on the right-side. On this zone, the message producer dispatched the 'given information' through the information about the admission and 'new information' through the image of students wearing alma mater jacket. By featuring the admission information, the message producer tries to gather the 'image' of students represented through the picture on the right side. On the upbottom zone, the message producer puts ideal things (information on admission (PMB) and departments that can be chosen by the prospective students on 
the upper of the billboard zone) and real things (the address and the contact of the university). The two-layered zoning of the billboards indicates the affirmation of one type of information with the others. The image of students wearing the alma mater jacket affirmed the admission information; and the information on the department by the university address and the contact number.

Salience is an aspect showing the elements of the billboards made to attract the attention of the audience/reader (Kress and Leuween, 2006: 177). It is shown by various degrees that appear on the choosing of foreground or background, size, color contrast, color sharpness, etc., and almost all of the billboards in this research use the colors identical to the university logo or the color tone that has become the characteristic of the university. The billboard of Universitas Atma Jaya Yogyakarta features yellow, the color of the university logo, as the background color, and a yellowish tone for the image. Since there is no color contrast between the image and other parts of the billboards, the content of the billboards, both information, and the image, become a unity. The billboard of Universitas Teknologi Yogyakarta uses red for the admission information background and blue for the image background. Universitas Sanata Dharma features maroon, similar to the color of the torch on the university logo. The only exception is perhaps the billboard of Universitas Sarjanawiyata Tamansiswa. Instead of using simple color identical to the university logo, it employs various colors. The word 'PMB' is orange, and the background is turquoise; the admission information (PMB) uses darker turquoise as background; the department employs black as the background, and; the address and contact number use white as the background color.

The aspect of framing sees the existence (or, instead, absence) of elements that frame a particular theme on a billboard advertisement. Framing, in Kress and Leuween (2006, p. 203204), also discusses connected elements (connection) and the disconnected elements (disconnection), both of which see the degree of connection between visual and verbal elements as well as the information framing of a billboard advertisement. If each mode is connected, the framing work to unify the information value and salience to become compact information. The information constructed on the private university billboard advertisements consists of two dominant modes: visual and linguistic. The linguistic information is built through the explanation of the university departments, scholarship, university accreditation, and university achievements.

On the billboard of Universitas Sarjanawiyata Tamansiswa, beside the image of students wearing the alma mater jacket, there are images of students wearing the traditional costume of Bali, dancing, and studying, showing that the student activities are not only academics. However, the linguistic and visual modes of the billboards of Universitas Sarjanawiyata Tamansiswa are not interconnected.

The image of students also appears on the billboard of Universitas Teknologi Yogyakarta. The students are portrayed standing hand in hand in the backyard of the campus. It showcases the campus infrastructure, namely the university building and spacious backyard as the background. The image of students appears on the billboard of Universitas Teknologi Yogyakarta. The students portrayed standing hand in hand in the backyard of the campus. It showcases the campus infrastructure, namely the university building and spacious backyard as the background. The image of students indicates the large number of students 
attending the university. A tag (The Better Choice) shows the linguistic mode. The relation between the linguistic and visual modes indicates the Universitas Teknologi Yogyakarta is not only 'a better choice' but also chosen by many students. However, the billboard does not explicitly indicate the audience or from which university Universitas Teknologi Yogyakarta is 'the better choice'.

The visual element, namely the image of students, frames the campus atmosphere. On the billboard of Universitas Atma Jaya Yogyakarta, the visual of students interacting with an older male holding a puppet (wayang) portrays a lesson about culture. It shows the image of a student who has just graduated, wearing a toga and a gown standing in front of the campus depicts a success. The billboard of Universitas Sanata Dharma unobtrusively uses the university campus as the background for the students means that for the university, the physical infrastructure is less significant than the development of the human resource. It is emphasized by the linguistic mode, which eventually strengthens the university identity through the intermodal relation of the billboard. On the billboard of Universitas Sanata Dharma, the words "Welcome, the Smart and Humanist Generation" strengthened the image of the smiling students. Further, there is a similar pattern found in the billboard of Universitas Atma Jaya Yogyakarta. Along with the visual of students, the billboard also features the university tagline (on the left side), namely "Excellent, Inclusive, Humanist, [with] Integrity".

\section{Identity and the Frame of Commodification}

Commodification is a value transformation of goods from the use-value to the exchange value. The transformation process is closely related to capitalism as a mode of production whose aims are to collect a bigger amount of capital (Mosco, 2009, pp. 128-129). In other words, everything which has the use-value is transformed into a commodity with exchange value and can be commercialized and produce a benefit.

In the process, commodification has a close relation to communication. The correlation between both aspect in two dimensions: first, the communication process as well as technology which possesses contribution in the general of commodification in the field of economy holistically; second, the commodification process works in a work environment as the communication process as a whole, so that various attempts to maintain as well as contradiction occurring in the commodification process which will influence the communication process a social practice (Mosco, 2009, p. 130).

This research has found that there are two types of identities appearing on the billboards: (1) the university identity which, in appearance, is emphasized through the specific color of the institution, accreditation status, and the use of alma mater suits; (2) other identities shown through the attributes used by the models, including tribal/ethnic identity and religious identity. One of the most interesting examples is the billboards of Universitas Atma Jaya Yogyakarta, and Universitas Sanata Dharma features diversity and cultural issues. The tribal/ ethnic (regional) and religious identities appear on the diverse physical characters and attributes models - Eastern Indonesia, Javanese, and Chinese-faced as well as hijab-wearing models showing Islamic religious identity.

The organizing of private education correlated with the commodification process, which eventually makes education itself a product. The identity on the billboard advertisement becomes the reflection of discourse about the commodification of higher education 
that appears through issue, ideology, and symbol. It arises in the billboards of Universitas Atma Jaya Yogyakarta, and Universitas Sanata Dharma is diversity and culture shown by the various physical appearances and attribute of the model featured on the billboard as a model who has the typical face of Indonesia Timur, Jawa, Tionghoa, as well as models wearing jilbab attribute which shows the identity of the religion of Islam.

As the symbol of the religion of the majority in Indonesia, namely Islam, the hijab appears on the billboard of all of the four universities, namely Universitas Atma Jaya Yogyakarta, Universitas Teknologi Yogyakarta, Universitas Sarjanawiyata Tamansiswa, dan Universitas Sanata Dharma. The hijab-wearing models on the billboards of Universitas Teknologi Yogyakarta and Universitas Sarjanawiyata Tamansiswaboth of which are universities without any religious affiliation-illustrate the reality of the diversity of student identity. For Universitas Atma Jaya Yogyakarta and Universitas Sanata Dharma, both Catholic universities, the hijab-wearing model is an appeal as non-exclusive educational institutions. The university not only accepts students of one religion but also that of various, others. It gives both universities an air of inclusiveness, an added value to attract prospective students hopefully. The emphasis of the hijab on the advertisement of Universitas Sanata Dharma and Universitas Atma Jaya shows the openness of the university to the differences, religious identity that is quite different from the ideology possessed by the university as well as showing the inclusivity of the institution.

The use of cultural symbols on the billboards of private universities indicates that higher education not solely about academic activities or job prospects. The identities featured on the billboards representatively work to show two opposite matters: First, there is an effort from the universities to shows the most simple character of their institutions. In other words, each campus wants to signify its exclusivity differing from other educational institutions. It is practiced by, for instance, featuring the image of the student wearing an alma mater suit that stands out from other billboard elements, enabling the audience to see the distinctive color of the alma mater suit as well as its shape (including the form of the university logo put on the jacket). The tagline show message enhancement of the exclusivity. The use of the words like 'prospective,' 'quality,' and 'BAN-PT accredited' on the billboard of Universitas Sarjanawiyata Tamansiswa (Pilihan Program Studi Prospektif, Berkualitas, dan Terakreditasi BAN-PT/The Choices of the Prospective Study Program, [with] Quality and Accredited by BANPT) explains the discourse of learning environment that has designed (quality), tested (prospective), and recognized (BAN-PT accredited).

Secondly, it shows the atmosphere of the diversity of the campus. In other words, there is inclusivity in educational practice on four of the billboards. There are images of students with various complexities and attributes. On the billboard of Universitas Atma Jaya Yogyakarta, Universitas Teknologi Yogyakarta, and Universitas Sanata Dharma, the college student models appear in a frame narrating the warm fellowship practiced at the universities. The billboard of Universitas Atma Jaya Yogyakarta does not explicitly exhibit what is offered by the institution. Instead, it features the picture of the student(s) interacting with a middle-aged man holding a puppet (wayang) that shows the 'desire of the youth to learn the local culture.' In tune with the tagline-Excellent, Inclusive, Humanist, [with] Integrity - the billboard directs the audience to pay more attention 
to (the student's) soft skill instead of hard skill. Universitas Sanata Dharma's billboard explicitly illustrates college life: a university student, on the campus, without a uniform, with a backpack on the shoulders, smiling. The tagline, "Welcome, the Smart and Humanist Generation" (Selamat Datang Generasi Cerdas Humanis), seems to explain the reason why the student is smiling. The billboard of Universitas Teknologi Yogyakarta also features quite a similar image, although captured from some distance that obscured the expression of the models. It is a group of people hand in hand while lifting one of their own feet as if they were dancing, showing the joy of being on the campus. The billboard features the tagline "The Better Choice," yet it does not explain what makes the university better than the others. Universitas Sarjanawiyata Tamansiswa put the image of students wearing traditional clothing and students dancing traditional dance at two different balloons on the billboard. However, the lack of interaction between the two images does not reinforce their goal to showcase the campus' plurality.

\section{CONCLUSION}

The identity that appears as a form of persuasive communication is also considerably used in the private university billboard advertisement in Yogyakarta. The goal is to make the institution closer to the market. Therefore, in private universities examined, there are Islamic symbols through the hijab worn by the model, although the university is Catholic. On another billboard, there is tribal identity emphasized to show the acceptance of the university to the diversity that exists in Yogyakarta. The institution's identity itself is through other pictures such as university building background and the use of the alma mater suits. In conclusion, although the billboards could display many issues, the diversity and culture presented as visual and linguistic modes are promising marketing materials for universities. As a commodity, cultural issues can potentially widen the market of the university as it can reach out to a scope of prospective students from various backgrounds.

\section{REFERENCES}

Ademilokun, M., \& Olateju, M. (2016). A Multiodal Discourse Analysis of Some Visual Image in the Political Rally Discourse of 2011 Electioneering Campaigns in Southwestern Nigeria. International Journal of Society, Culture and Language, 4(1), 1-19.

Banda, F., \& Oketch, O. (2011). Localizing HIV/AIDS Discourse in a Rural Kenyan Community. Journal of Asian and African Studies, 46(1), 19-37.

BBC. (2016). Kisah di Balik Penurunan Baliho Mahasiswi Berhijab. Kisah di Balik Penurunan Baliho Mahasiswi Berhijab

Cheong, Y. Y. (2004). The construal of ideational meaning in print advertisement. In Multimodal discourse analysis: Systemicfunctional perspectives.

Collier, M. J. (2015). Cultural Identity and Intercultural Communication. In L. A. Samovar, A. Larry, \& R. Porter (Eds.), Intercultural Communication: A Reader (14th ed., pp. 53-61). Cengage.

Cook, G. (2001). The Discourse of Advertising. In The Discourse of Advertising. https://doi. org/10.4324/9780203978153

Haryono, S. R., \& Putra, D. K. S. (2017). Identitas Budaya Indonesia: Analisis Semiotika Roland Barthes Dalam Iklan Aqua Versi "Temukan Indonesiamu." Acta Diurna, 13(2), 67-88.

Ikaria-Maina, N. (2014). Discourse of Advertising: Reference to Kiswahili and English Adverts in Kenyan Media. International Journal of 
Science and Research (IJSR), 3(11), 1562-1568.

Jawapos. (2018). Predikat Jogja Sebagai Kota Pendidikan Dipertaruhkan. https://www.jawapos.com/ jpg-today/09/03/2018/predikatjogja-sebagai-kota-pendidikandipertaruhkan/

Kasali, R. (2002). Manajemen Periklanan, Konsep dan Aplikasinya di Indonesia. Grafiti.

Kottler, P., \& Armstrong, G. (2009). PrinsipPrinsip Pemasaran. Ed. 12, Jilid 1. Jakarta: Erlangga.

Kress, Gunther;, \& Leeuwen, T. V. (2006). Reading Images The Grammar of Visual Design-second edition. In Routledge.

Kress, Gunther. (2013). Multimodal discourse analysis. In The Routledge Handbook of Discourse Analysis. https://doi. org/10.4324/9780203809068-10

Kumparan. (2018). Pendaftar PTN di Yogyakarta Jalur SBMPTN Meningkat 3000 Peserta. https:// kumparan.com/tugujogja/pendaftarptn-di-yogyakarta-jalur-sbmptnmeningkat-3-000-peserta

Lupiyoadi. (2011). Manajemen Pemasaran Jasa Teori dan Praktik. In Salemba Empat. https://doi.org/10.1002/cb.84

Mosco, V. (2009). The political economy of communication. In The Political Economy of Communication. https:// doi.org/10.4135/9781446279946

O'Halloran, K. L. (2004). Multimodal Discourse Analysis: Systemic Functional Perspective. In K. L. O'Halloran (Ed.), Multimodal Discourse Analysis: Systemic Functional Perspective (pp. 1-7). Continuum.

OAAA. (2017). 7 OOH Trends in 2017. http://oaaa.org/DesktopModules/ SearchBoost/DownloadDoc. ash $x$ ?filepid $=0 \&$ file $=7564$
Pitaloka, D. A. (2016). Universitas Sanata Dharma Tolak Turunkan Baliho Mahasiswi Berhijab. Rappler. https://www.rappler.com/indonesia/ berita/155062-sanata-dharmabaliho-mahasiswi-berjilbab

Putri, L. A. (2016). Representasi Kebebasan dalam Iklan Televisi: Analisis Wacana Multimodal Iklan Televisi Tri Versi Bebas Itu Nyata, A Mild Versi Manimal Dan Fair \& Lovely.

Rini, G. . (2018). Peningkatan Top Of Mind Melalui Frekuensi Penayangan, Daya Tarik Pesan dan Waktu Penayangan Iklan. Media Ekonomi, 18(2), 95108.

Ristekdikti. (2017). Kopertis Wilayah V-DI Yogyakarta. http://kelembagaan. ristekdikti.go.id/index.php/kopertiswilayah-v-d-i-yogyakarta/

Rohmiati. (2010). Penggunaan Identitas Etnik dalam Iklan Televisi. Jurnal ISIP, 37-47.

Samovar, L. A., Porter, R. E., McDaniel, E. R., \& Roy, C. S. (2015). Communication Between Cultures. Cengage.

Sinar, T. . (2012). Teori \& Analisis Wacana Pendekatan Linguistik Sistemik Fungsional. Mitra.

Sopandi, E. (2011). Strategi Promosi Penerimaan Mahasiswa Baru untuk PTS(Tinjauan Atas Kegiatan Promosi Pts Di Jawa Barat Tahun 2010). Jurnal Manajerial, 10(1), 87101.

Sulastri, \& Ronidin. (2014). Fenomena Bahasa Baliho Sebagai Identitas Diri Tokoh Cerminan Karakter Budaya: Kajian Semiotika. Jurnal Sosioteknologi, 13(1), 48-59.

Susanto, E. H. (2014). Dinamika Pesan Iklan. Jurnal Komunikasi Universitas Gunadarma, 6(2), 1-9.

Van Leeuwen, T. (2005). Introducing Social Semotics. Routledge. 